\title{
Taxonomic and typological structure of the flora of Eastern Podilia (Ukraine)
}

\author{
Oleksandr Mudrak ${ }^{1 \star}$, \\ Yuliia Ovchynnykova ${ }^{2}$, \\ Halyna Mudrak', \\ Halyna Tarasenko ${ }^{1}$ \\ ${ }^{1}$ Communal Higher \\ Educational Institution \\ "Vinnytsia Academy \\ of Continuing Education", \\ Hrushevskogo St. 13, \\ Vinnytsia 21100, Ukraine \\ ${ }^{2}$ Vasyl' Stus Donetsk \\ National University, \\ 600-richcha St. 21, \\ Vinnytsia 21021, Ukraine \\ ${ }^{3}$ Vinnytsia National \\ Agrarian University, \\ 3 Sonyachna St., \\ Vinnytsia 21008, Ukraine
}

\begin{abstract}
On the basis of herbarium data, literary and cartographic sources, own field research with subsequent critical-system processing of the collected material, an inscription of the flora of Eastern Podilia was compiled, which includes 1210 species belonging to 526 genera and to 123 families. The taxonomic structure of the flora of the investigated area includes five divisions, where the Magnoliophyta division with 1183 species is dominant (97.2\%). The authors have also established the biomorphological structure of phytogenic manures of the region, $88.6 \%$ of which belong to herbaceous plants. The majority of species belong to polycarpic $736(60.8 \%)$, monocarpic (17.4\%), and young (10.4\%) species. It should be noted that when assessing phytobiota by the Raunkiaer eco-biomorphic index, it was found that hemicryptophytes (47.9\%) and tetophytes (22.2\%) prevailed in the studied flora. Cryptophytes, which are divided into geophytes, gelophytes, and hydrophytes, constituted $17.6 \%$, and phanerophytes and hamefites $12.3 \%$. As a result of studies on the ecological and coenotic structure of the flora of the region, there are 16 categories of ecological structure. The dominant group is the meadow-steppe - 191 species $(15.8 \%)$, rayon -185 species $(15.3 \%)$, and non-forest species -183 species $(15.1 \%)$ of vegetation.
\end{abstract}

Keywords: species, phytodiversity, ecological and coenotic analysis, factors

\section{INTRODUCTION}

Plant diversity plays an important role in the health of ecosystems and well-being of society in general and individuals in particular (Gerstner et al., 2014). Plants are a key element in the research and conservation of biodiversity on the Earth (Bermudez, Cantos, 2012; Bhojwani, Dantu, 2013). The study into and investigation of biodiversity include the definition of the composition of its species (Mariničová, Eliáš, 2016; Genung et al.,

*Corresponding author. Email: ov_mudrak@gmail.com
2017) that is impossible without a clear view of natural (Zuo et al., 2012; Mutke et al., 2014; SalasMorales et al., 2015; Kuzemko et al., 2016) and anthropogenic (Kadeba et al., 2015; Řepka et al., 2015; Maltseva et al., 2017) factors in the formation of the variety of the territory. For Eastern Podilia (Ukraine), phytodiversity of species is a subject to be studied and researched.

Phytodiversity is a component of biodiversity, proportional to the number of typological elements (taxa, syntaxa, etc.) of a particular biosystem and to the degree of their variability (Honcharenko, 2003). It is known that the environmental 
value of a natural area is directly proportional to the variety of phytobiota with a significant number of rare objects and inversely proportional to significant anthropogenic influence (Andrienko, 1981; Chandra, Kewat, 2017). Floristic diversity is determined by the number of taxa within a certain area (Honcharenko, 2003). The level of species phytodiversity is taken as the basis for the study of other manifestations of diversity (Mudrak et al., 2015).

It is also important and necessary to assess the state of phytodiversity according to the typological structure. Indeed, the significant ecological and geographical heterogeneity of places of growth in the process of evolution plays a significant role in the development of modern biological diversity of living organisms, including autotrophic, which are the primary and most active link of all ecosystem processes and ensure the functioning, stability, and ecological balance of the biosphere due to the circulation of substances, energy and information. Currently it is relevant to study the peculiarities of vascular plants and the patterns of their distribution in the environment, depending on the geographical and environmental conditions of their existence. The taxonomictypological assessment of the biota is among the main methods and approaches in the research. The biomorphological, ecological, and ecological-cenotic structures of the biota were examined.

Investigation of flora, its ecological and cenotic analysis, protection and balanced use are one of the high-priority tasks in the research, conservation and reproduction of biodiversity, monitoring of the rates of adventisation of local flora and invasive processes (Litvinskaia, 2012; Kumar, 2014; Khan et al., 2016). (Baranovski et al., 2016; Lykholat et al., 2017), which provides a variety of landscapes and functions as structural elements in the formation of a regional ecological network.

\section{MATERIALS AND METHODS}

In order to get a complete view of the state of Eastern Podilia phytodiversity, an analysis of the vegetation of the investigated region was initially carried out, a systematic list was drawn up, and quantitative composition of the plants was determined. After geobotanical research, the general floristic list was drawn up in a classified or alphabetical order. The first method of description of taxa was preferred. For this purpose, the system of A. L. Takhtadzhan (1987) that was adopted in the majority of modern Ukrainian floristic reports was used. According to this system, divisions, classes, families of higher plants, and families and species are put in an alphabetical order using Latin names. After that, a systematic analysis of the flora was carried out, its variety was assessed, and the flora was compared with neighbouring and remote vegetative groups. As the main indicators of the systematic structure, the ratios between different groups of higher plants were examined. These ratios were expressed in numbers that represent the amount of species of each systematic group within the defined flora. The floristic spectrum was drawn up on the basis of various features, the most important of which are the spectra reflecting the composition and sequence of location: families by the number of species; families by the number of genera; genera by the number of species. The comparison and the final analysis of the state of a particular area of Eastern Podilia were conducted on this basis.

The taxonomic-typological structure of the flora of vascular plants of Eastern Podilia is drawn up on the basis of archival and herbarium data, cartographic and literary sources, field studies, followed by the critical-system processing of the collected material. The materials of the National Herbarium of Ukraine (M. G. Kholodny Institute of Botany of the National Academy of Sciences of Ukraine), Herbarium Funds of Mykola Grishko National Botanic Garden of the National Academy of Sciences of Ukraine, the National Museum of Natural History of Ukraine, the National $\mathrm{Mu}$ seum of Natural History of the National Academy of Sciences of Ukraine, local museums of Eastern Podilia, Karmelyukove Podilia National Nature Park, Tsentralne Podilia National 
Nature Park, Dnister, Murafa, Serednie Pobuzhia, Nemyrivske Pobuzhia Regional Natural Parks (Volovik, Mudrak, 2007; Mudrak, 2008; Yavorskaia, 2005; Mudrak, 2009; Mudrak et al., 2015; Mudrak et al., 2006; Mudrak, Mudrak, 2013; Patyka et al., 2003; Andrienko et al., 1985; Didukh, 2009; Mosiakin, Phedorchuk, 1999).

\section{RESULTS AND DISCUSSION}

The systematic spectra of the flora show diversity at the level of systematic ranks of species complex. That is, if all divisions, families that make up the flora are arranged in the decreasing order of the species diversity, a general generic floristic spectrum will be obtained. The greatest attention was focused on the first part of the spectrum (about 10-15 taxa), which consisted of the richest families or genera (Malyshev, 1972).

The spectra reflect the main peculiarities of the systematic composition and therefore, they are used to characterize the flora. Moreover, in contrast to absolute indices of flora, relative ones of a systematic structure are stabilized values, which makes it possible to compare the latter in diverse flora (Tolmachev, 1970).

During the period of field expeditions, we carried out 103 field descriptions $(100 \times 100)($ Fig. 1). As a result of studies in Eastern Podilia, where various types of anthropogenically-disturbed areas and natural phytocenoses were studied, 1210 types of vascular plants were identified, which belong to 526 genera and 123 families.

During the research of the systematic structure of the flora in the investigated area it was found that species belong to five groups (Table 1).

The groups of Lycopodiophyta, Equisetophyta, Polypodiophyta and Pinophyta play a minor role in the formation of the species diversity of the flora of the investigated region and make up $2.2 \%$ of the species, which are distributed in Eastern Podilia.

The systematic structure of the flora is dominated by the Magnoliophyta division, which includes 1183 species (97.2\%). The species related

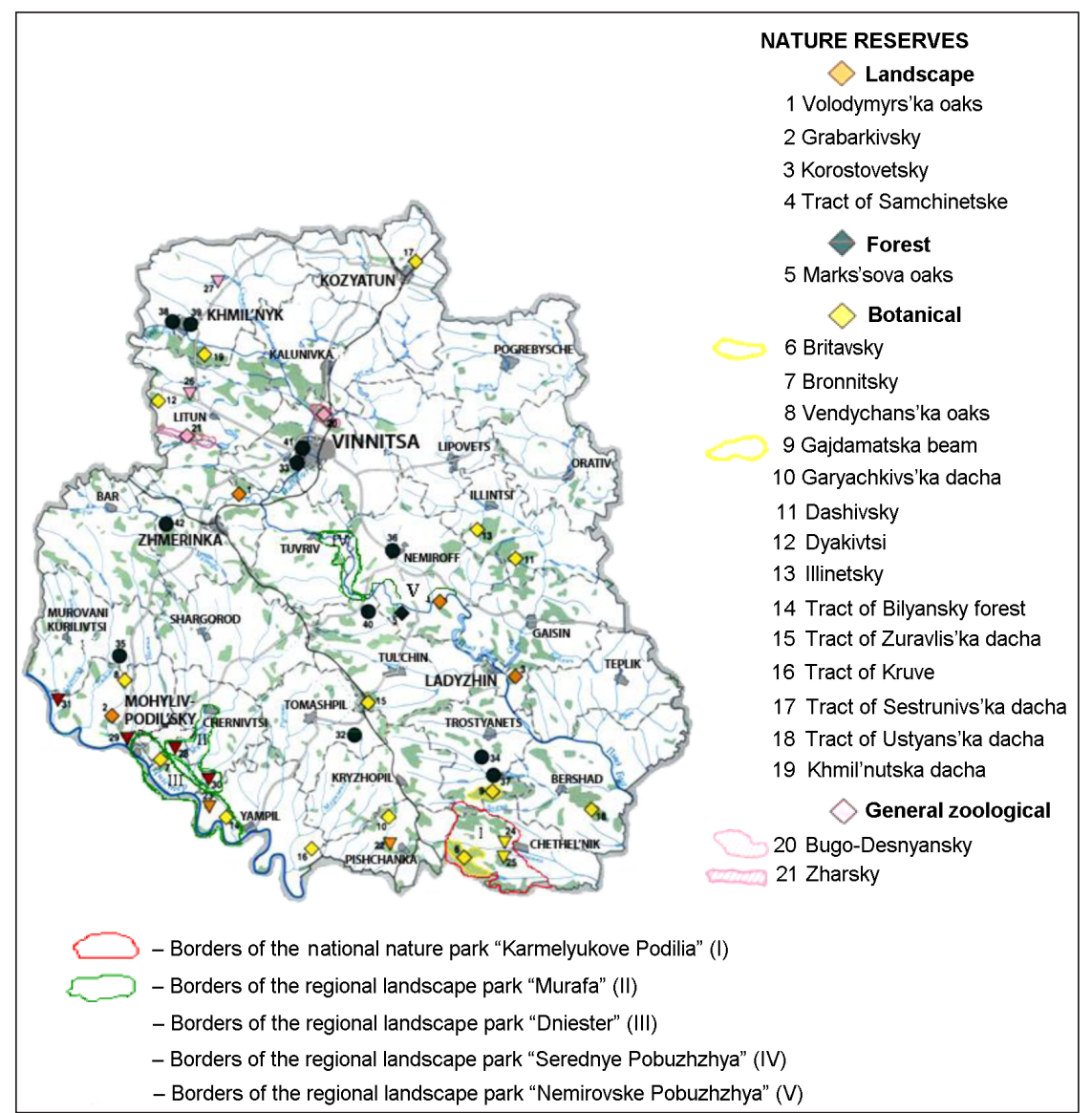

Fig. 1. Map-scheme of field studies of the flora of Eastern Podilia 
Table 1. Systematic structure of the flora of vascular plants of Eastern Podilia

\begin{tabular}{c|c|c|c|c|c|c}
\hline \multirow{2}{*}{ Division } & \multirow{2}{*}{ Families } & \multirow{2}{*}{ Genera } & \multirow{2}{*}{ Species } & \multicolumn{3}{|c}{ \% of the total amount } \\
\cline { 6 - 8 } & & & & families & genera & species \\
\hline Lycopodiophyta (Lycophyta) & 1 & 1 & 1 & 0.8 & 0.2 & 0.1 \\
\hline Equisetophyta (Sphenopsida) & 1 & 1 & 9 & 0.8 & 0.2 & 0.7 \\
\hline Polypodiophyta (Fern) & 9 & 11 & 15 & 7.3 & 2.1 & 1.2 \\
\hline Pinophyta (Gymnosperms) & 1 & 1 & 2 & 0.8 & 0.2 & 0.2 \\
\hline Magnoliophyta (Angiosperms) & 111 & 512 & 1183 & 90.2 & 97.3 & 97.8 \\
\hline Total & 123 & 526 & 1210 & & & \\
\hline
\end{tabular}

to Magnoliophyta belong to two classes of Magnoliophyda (78.8\%) and Liliopsida (18.9\%).

The taxonomic spectrum (of families and species) of phytobiota gives an idea of the composition and ratio of leading families and their ranks depending on the number of species included in these families. The family spectrum of leading families of phytobiota consists of 26 families, 15 of them reflect the main properties of the flora (Table 2).

Five families of Asteraceae with 146 species (12.1\%), Poaceae - 78 (6.4\%), Rosaceae - 73 species (6.0\%), Fabaceae - 69 (5.7\%), and Lamiaceae - $68(5.6 \%)$ are dominant. Fifteen families in the generic spectrum also include such families as Brassicaceae, Scrophulariaceae, Apiaceae, Cyperaceae, Caryophyllaceae, Ranunculaceae, Chenopodiaceae, Boraginaceae, Liliaceae, Euphorbiaceae, and the amount of species in these families varies from 19 to 59 species (Table 2).

The dominant families make up about $67.4 \%$ of the investigated flora. Almost $11.4 \%$ of the species belong to families whose generic

Table 2. Spectrum of dominant families of phytobiota of Eastern Podilia

\begin{tabular}{|c|c|c|c|c|c|c|}
\hline \multirow[t]{2}{*}{ Family } & \multirow[t]{2}{*}{ Rank } & \multirow{2}{*}{$\begin{array}{l}\text { The number of gen- } \\
\text { era in the family }\end{array}$} & \multirow{2}{*}{$\begin{array}{l}\text { The amount } \\
\text { of species }\end{array}$} & \multicolumn{2}{|c|}{$\begin{array}{c}\% \text { of the total } \\
\text { amount }\end{array}$} & \multirow{2}{*}{$\begin{array}{c}\text { Ratio species/ } \\
\text { genera }\end{array}$} \\
\hline & & & & genera & species & \\
\hline Asteraceae & $\mathrm{I}$ & 56 & 146 & 10.6 & 12.1 & 2.6 \\
\hline Poaceae & II & 36 & 78 & 6.8 & 6.4 & 2.2 \\
\hline Rosaceae & III & 23 & 73 & 4.4 & 6.0 & 3.2 \\
\hline Fabaceae & IV & 21 & 69 & 4.0 & 5.7 & 3.3 \\
\hline Lamiaceae & $\mathrm{V}$ & 28 & 68 & 5.3 & 5.6 & 2.4 \\
\hline Brassicaceae & VI & 34 & 59 & 6.5 & 4.9 & 1.7 \\
\hline Scrophylariaceae & VII & 16 & 51 & 3.0 & 4.2 & 3.2 \\
\hline Apiaceae & VIII & 33 & 50 & 6.3 & 4.1 & 1.5 \\
\hline Cyperaceae & IX & 8 & 47 & 1.5 & 3.9 & 5.9 \\
\hline Caryophyllaceae & $\mathrm{X}$ & 26 & 45 & 4.9 & 3.7 & 1.7 \\
\hline Ranunculaceae & $\mathrm{XI}$ & 19 & 41 & 3.6 & 3.4 & 2.2 \\
\hline Chenopodiaceae & XII & 4 & 25 & 0.8 & 2.1 & 6.3 \\
\hline Boraginaceae & XIII & 14 & 24 & 2.7 & 2.0 & 1.7 \\
\hline Liliaceae & XIV & 10 & 20 & 1.9 & 1.7 & 2.0 \\
\hline Euphorbiaceae & $\mathrm{XV}$ & 2 & 19 & 0.4 & 1.6 & 9.5 \\
\hline Total & & 330 & 815 & 62.7 & 67.4 & 2.5 \\
\hline
\end{tabular}


diversity is represented by $9-16$ species. Among them are Rubiaceae, Polygonaceae, Orchidaceae, Violaceae, Campanulaceae, Geraniaceae, Salicaceae, Primulaceae, Potamogetonaceae, Juncaceae, Equisetaceae.

The average number of species in the genera of dominant families varies from 1.5 in Euphorbiaceae to 9.5 in Apiaceae (Table 2).

Another 33 families are monospecies, in general, they constitute $2.7 \%$ of the total phytobiota. Comparing the family spectrum of our research, it turned out that the dominant families of the region are almost the same, but put in a different order. It proves that the investigated area is approaching the vegetation of the forest-steppe in terms of the family spectrum of species. It is not obligatory that higher taxa with a large number of species play a more important role in the formation of vegetation than taxa of the same rank, which include a smaller number of species. It is also true that taxa, which include a relatively small number of species, can play an equally important role in the formation of vegetation as taxa of the same rank, which include more species. It is especially typical for man-made ecotops regarding ruderal and segetal species, concentrated in separate families (Amaranthaceae, etc.). An example of such "ruderal-segetal families" can be the family Chenopodiaceae (the 12th place in the family spectrum, 25 species $(2.1 \%)$ ), which includes mainly synanthropic plants and plays an important role in the formation of the flora of the investigated areas. These species are mainly spread on the grassland and edges of fields. A remarkably high role of the family $C y$ periaceae (the ninth in the spectrum of leading families, 47 species) is, on the one hand, due to the expansion of the species of this family on meadows, steppes, pastures and banks of ponds and rivers of the studied areas and, on the other hand, it can be explained by sufficient preservation of the paludophyton in the flora of agricultural areas of the region. Thirty genera are dominant in the generic spectrum of flora and make up $28.4 \%$ of the total number of species. Other $71.6 \%$ of genera are represented by 1-6 species. The results of Table 3 indicate that the leading families include the leading genera, where the number of species ranges from 7 to 36 (Table 3).

The genera Carex L. (36 species, 3\%), Euphorbia L. (18 species, 1.5\%), Rosa L. and Veronica L. (17 species, 1.4\%) Potentilla L. and Viola L. (14 species, 1.2\%), Chenopodium L. and Trifolium L. (13 species, 1.1\%), Ranunculus L. (12 species, 1\%), Campanula L., Centaurea L., Galium L., Geranium L., Potamogeton L. (11 species, $0.9 \%)$ and others are dominant. Dominant genera combine 344 species (28.4\%).

The statement that in modern floristics the preference is given to 10-12 leading families, which reflect the main part of the floristic spectrum, is fair and proven. The presence of such leading families is typical of the Holarctic flora and, accordingly, of the specific flora of Eastern Podilia.

A small number of families plays a leading role in species diversity, but the number of families with a small number of species predominates quantitatively.

Typological structure of the flora of Eastern Podilia. The typological assessment of the biota is one of the most used methods and approaches in the investigation of the region. Biomorphological (according to indices of life forms in terms of habitat and biomorph of Raunkiaer (1934) ecological-cenotic, ecological (concerning water and light regime) structures, genesis and sozological confinement of the species are investigated. That is why it is necessary and compulsory to be aware of the typological structure of the phytodiversity of the investigated area.

Biomorphological structure of higher vascular plants of the region. Life forms inherited during the evolution are formed historically to ensure the adaptation of living organisms to the environmental conditions. The biomorphological structure of the flora includes the life form in terms of habitat and the eco-biomorph of Raunkiaer (1934).

To determine the characteristic features of the flora it is necessary to identify the types of life forms of the species that form it. The biomorphological analysis is based on the linear system 
Table 3. Spectrum of the leading genera of the flora of explored phytocenoses of Eastern Podilia

\begin{tabular}{|c|c|c|c|c|}
\hline Family & Genus & Rank & $\begin{array}{c}\text { Number of } \\
\text { species }\end{array}$ & $\begin{array}{c}\% \text { of the total } \\
\text { number }\end{array}$ \\
\hline Cyperaceae & Carex L. & 1 & 36 & 3.0 \\
\hline Euphorbiaceae & Euphorbia L. & 2 & 18 & 1.5 \\
\hline Rosaceae & Rosa L. & $3-4$ & 17 & 1.4 \\
\hline Scrophylariaceae & Veronica L. & $3-4$ & 17 & 1.4 \\
\hline Rosaceae & Potentilla L. & $5-6$ & 14 & 1.2 \\
\hline Violaceae & Viola L. & $5-6$ & 14 & 1.2 \\
\hline Chenopodiaceae & Chenopodium L. & $7-8$ & 13 & 1.1 \\
\hline Fabaceae & Trifolium L. & $7-8$ & 13 & 1.1 \\
\hline Ranunculaceae & Ranunculus L. & 9 & 12 & 1.0 \\
\hline Campanulaceae & Campanula L. & $10-14$ & 11 & 0.9 \\
\hline Asteraceae & Centaurea L. & $10-14$ & 11 & 0.9 \\
\hline Rubiaceae & Galium L. & $10-14$ & 11 & 0.9 \\
\hline Geraniaceae & Geranium L. & $10-14$ & 11 & 0.9 \\
\hline Potamogetonaceae & Potamogeton $\mathrm{L}$. & $10-14$ & 11 & 0.9 \\
\hline Juncaceae & Juncus L. & $15-16$ & 10 & 0.8 \\
\hline Fabaceae & Vicia L. & $15-16$ & 10 & 0.8 \\
\hline Asteraceae & Cirsium L. & $17-23$ & 9 & 0.7 \\
\hline Caryophyllaceae & Dianthus L. & $17-23$ & 9 & 0.7 \\
\hline Equisetaceae & Equisetum L. & $17-23$ & 9 & 0.7 \\
\hline Fabaceae & Astragalus L. & $17-23$ & 9 & 0.7 \\
\hline Fabaceae & Lathyrus L. & $17-23$ & 9 & 0.7 \\
\hline Poaceae & Festuca L. & $17-23$ & 9 & 0.7 \\
\hline Lamiaceae & Salvia L. & $17-23$ & 9 & 0.7 \\
\hline Asteraceae & Artemisia L. & $24-26$ & 8 & 0.7 \\
\hline Poaceae & Poa L. & $24-26$ & 8 & 0.7 \\
\hline Polygonaceae & Rumex L. & $24-26$ & 8 & 0.7 \\
\hline Alliaceae & Allium L. & $27-30$ & 7 & 0.6 \\
\hline Liliaceae & Gagea L. & $27-30$ & 7 & 0.6 \\
\hline Asteraceae & Hieracium L. & $27-30$ & 7 & 0.6 \\
\hline Asteraceae & Inula L. & $27-30$ & 7 & 0.6 \\
\hline
\end{tabular}

of life forms, which makes it possible to compare eco-biomorphs in terms of any parameters.

About $88.6 \%$ belongs to herbaceous plants in the biomorphological spectrum of the phytodiversity of the studied areas of the region. Most species belong to Polycarpics - 736 (60.8\%).
Monocarpics and few-year plants make up $17.4 \%$ and $10.4 \%$, respectively (Table 4 ).

The bush phytobiota of the investigated areas of the region is represented by 62 species, but the genera Euonymus L., Chamaecytisus L., Crataegus L., Rosa L., Salix L. are the most common. 
Table 4. Biomorphological spectrum of vascular plants of Eastern Podilia

\begin{tabular}{c|c|c}
\hline Life forms & Number of species & \% of the total number \\
\hline Tree & 48 & 4.0 \\
\hline Bush & 62 & 5.1 \\
\hline Shrub & 28 & 2.3 \\
\hline Few-year plants & 126 & 10.4 \\
\hline Policarpics & 736 & 60.8 \\
\hline Monocarpics & 210 & 17.4 \\
\hline
\end{tabular}

About $4 \%$ of the species belong to trees. They form the basis of forests, forest edges, and garden and park areas. The most common are Acer negundo L., Acer campestre L., Betula pendula Roth., Acer tataricum L., Gleditsia triacanthos L., Carpinus betulus L., Robinia pseudoacacia L., Fagus sylvatica L., Quercus robur L., Quercus rubra L., Aesculus hippocastanum L., Fraxinus excelsior L., Armeniaca vulgaris Lam., Cerasus avium L. Moench, Malus domestica Borkh., Sorbus aucuparia L., Populus alba L., Salix fragilis L., Staphylea pinnata L., Tilia cordata Mill., Ulmus glabra Huds, etc.

The shrubs in the flora of Eastern Podilia make up about $2.3 \%$, the main representatives are Artemisia abrotanum L., Hedera helix L., Thymus marschallianus Willd., Rubus caesius L., Daphne mezereum L., Caragana frutex L., K. Koch. Vaccinium myrtillus L. and others.

After the evaluation of phytobiota in terms of eco-biomorph of Raunkiaer (1934), we found that hemicryptophytes and terophytes dominated the investigated area and made up 47.9 and $22.2 \%$, respectively. Cryptophytes, which are divided into geophytes, gelophytes and hydrophytes constitute $17.6 \%$ in the investigated flora. Phanerophytes and hamephytes make up 12.3\% (Table 5).

Thus, polycarpics $(60.8 \%)$ dominate in the ecotones regarding their biomorphological structure, 520 species (43\%) of them belong to hemicryptophytes and geophytes (12\%). The biomorphological structure makes it possible to estimate the value of species and their place in the agro-landscape and define the diversity of a particular area where they grow.

Ecological cenotic analysis of the state of higher vascular plants in the region. The ecological structure reflects the distribution of species of flora in different ecological groups depending on the environment and the norms of reaction to the environmental conditions. An ecological analysis allows us to determine the dependence of the structure of the flora on the factors of the environment. Water and soil, i.e., the level of provision of plants with moisture and nutrients, are considered to play the most important role in determining the patterns of formation of flora.

Table 5. Ecobiomorph of the phytobiota of Eastern Podilia according to K. Raunkiaer (1934)

\begin{tabular}{ccc}
\hline Ecobiomorph & Amount & \% of the total amount \\
\hline Phanerophyte & 45 & 3.7 \\
\hline Hamephyte & 104 & 8.6 \\
\hline Hemicryptophyte & 579 & 47.9 \\
\hline Geophyte & 151 & 12.5 \\
\hline Gelophyte & 26 & 2.1 \\
\hline Hydrophyte & 36 & 3.0 \\
\hline Terophyte & 269 & 22.2 \\
\hline
\end{tabular}


We analyzed the vegetation state of Eastern Podilia regarding water (Table 6) and light (Table 7) regimes.

Considering the ecological structure of phytobiota of the studied region, it should be noted that $35.7 \%$ and $25.9 \%$ of the species belong to xeromesophytes and mesoxerophytes, respectively, 432 and 313 species. The predominance of these groups characterizes the studied area, which is typical for the area of the Right Bank forest steppe. As the studied areas belong to different types of ecosystems, the xerophyte and mesoxerophyte group of plants is spread in the steppe areas whereas mesophyte and mesoxerophyte are found in the forest, meadow and coastal regions. The predominance of a particular ecological group of plants may vary between mesophyte and xerophyte phytobiota within the Right Bank forest steppe, where the forest, steppe and agrocenosis are located next to each other, following one after another.

The most spread mesophytes are Adonis vernalis L., Agrimonia eupatoria L., Anemone sylvestris L., Anthriscus sylvestris (L.) Hoffm., Chelidonium majus L., Geum urbanum L., Rosa canina L., Rubus idaeus L., Urtica dioica L., Viola odorata L., they are common not only in the forest, but also in phytocenoses and other ecotopes.

Representatives of xerophytes are mainly spread in the steppe. Typical representatives of xerophytes are Agropiron pectinatum (Bieb) Beauv., Astragalus austriacus Jacq., Astragalus dasyanthus Pall., Centaurea pseudocoriacea Dobrocz., Digitaria ischaemum (Schreb.) Muehl., Euphorbia pseudoglareosa Klokov, Leopoldia

Table 6. Ecological structure of vascular plants of Eastern Podilia regarding water regime

\begin{tabular}{ccc}
\hline Ecological group & Amount & $\begin{array}{c}\text { \% of the total } \\
\text { amount }\end{array}$ \\
\hline Hygrophyte & 133 & 11.0 \\
\hline Hydrophyte & 42 & 3.5 \\
\hline Xeromesophyte & 432 & 35.7 \\
\hline Xerophyte & 69 & 5.7 \\
\hline Mesophyte & 221 & 18.3 \\
\hline Mesoxerophyte & 313 & 25.9 \\
\hline
\end{tabular}

tenuiflora (Tausch) Heldr., Marrubium peregrinum L., Muscari neglectum Guss., Nonea pulla DC., Nonea rossica Steven, Stipa capillata L., Stipa lessingiana Trin. \& Rupr., Teucrium polium L., Tribulus terrestris L., Trinia multicaulis Schischk., Veronica sublobata M. A. Fisch., Viola ambigua Waldst. \& Kit, etc.

Hygrophytes and hydrophytes are spreading wider in the landscapes of the region. Their parts in the structure of the flora are 3.5\% and $11 \%$, recpectevly. The most common representatives of these groups are species of the genera Equisetum L., Carex L., Eleocharis L., Lemna L., Glyceria L., Juncus L., Iris L., Potamogeton L., Sparganium L., Gnaphalium L., Mentha L., Scutellaria L., Lytrum L., etc.

One of the main sources of energy for all living organisms is the energy of the sun. Only one group of organisms, i.e., green plants and photosynthesizing organisms, can make a direct use of solar energy. All other organisms, in essence, absorb solar energy, that is converted by green plants into the energy of chemical bonds. The light is very important for vegetation: both for the development of living forms and plant communities, and for the local distribution of plants. The changes in light intensity and its duration have a significant effect on plants. In the case of insufficient lighting, plants don't grow well, they weaken and die.

Investigating the structure of the flora of the region regarding the light regime, we have found that the main part of the species belongs to the skiophytes, i.d. shade-loving species and helioskiophytes - species of plants that grow

Table 7. Ecological structure of vascular plants of Eastern Podilia regarding light regime

\begin{tabular}{c|c|c}
\hline Ecological group & $\begin{array}{c}\text { Amount of } \\
\text { species }\end{array}$ & $\begin{array}{c}\text { \% of the total } \\
\text { amount }\end{array}$ \\
\hline Heliophytes & 386 & 31.9 \\
\hline Helioskiophytes & 390 & 32.2 \\
\hline Skioheliophytes & 44 & 3.6 \\
\hline Skiophytes & 390 & 32.2 \\
\hline
\end{tabular}


better in shaded places, but can also grow in areas with sufficient light (Table 7). The number of species of investigated flora belonging to this group constitutes 390 species, or $32.2 \%$ of the total amount. Heliophytes, sun-loving species, make up about $32 \%$ in the studied flora. These are mainly species of meadow and steppe ecosystems.

The ecological structure of the flora of Eastern Podilia regarding the water regime belongs to the vegetation of the Right Bank forest steppe where the groups of xeromesophyte and mesoxerophyte phytobiota prevail, and regarding the light regime it is represented by skiophytes, helioskiophytes and heliophytes. The investigated area is characterized as a transitional zone from the mesophytic group of vegetation to xerophytes.

The ecological-cenotic structure of vegetation reflects the quantitative correlation of phytobiotic species belonging to certain phytocenotypes. We distinguished the following categories within phytocenoses: psammophytes, halophytes, meadow, meadow-steppe, meadow-bog, forest edge, forest coreal, forest nemorose, forest-marsh, marsh, water, coastalwater, ruderal, segetal, species with a wide ecological amplitude, petrophytes, limestone, cretaceous, etc., cultivated (Table 8).

As a result of studies of the ecological cenotic structure of the flora of the region, the dominant vegetation is meadow-steppe with 191 species (15.8\%), meadow with 185 species (15.3\%) and forest nemorose with 183 species (15.1\%). The predominance of forest nemorose and meadow-steppe vegetation has appeared to be typical for this area.

The diversity and fragmentation of the studied area are presented by petrophytes, limestone, halophytes and psammophytes. The most common psammophytes are Linaria genistifolia (L.) Mill., Myosotis micrantha Pall. ex Lehm., Vulpia myuros (L.) C. C. Gmel., petrophytes are Alyssum calycinum L., Asparagus verticillatus L., Nonea pulla DC., Silene longiflora L., halophytes are Althaea officinalis L., Juncus gerardii Loisel., Ononis intermedia C. A. Mey. ex Rouy, Trifolium fragiferum $\mathrm{L}$.

The most widespread species in the studied phytocenoses are the representatives of forest

Table 8. Ecological and cenotic structure of phytobiota of Eastern Podilia

\begin{tabular}{|c|c|c|}
\hline Ecological and cenotic structure & Amount & $\%$ of the total amount \\
\hline Psammophytes & 26 & 2.1 \\
\hline Halophytes & 12 & 1.0 \\
\hline Meadow & 185 & 15.3 \\
\hline Meadow-steppe & 191 & 15.8 \\
\hline Meadow-bog & 126 & 10.4 \\
\hline Forest edge & 74 & 6.1 \\
\hline Forest coreal & 41 & 3.4 \\
\hline Forest nemorose & 183 & 15.1 \\
\hline Forest marsh & 35 & 2.9 \\
\hline Marsh & 37 & 3.1 \\
\hline Water & 45 & 3.7 \\
\hline Coastal-water & 27 & 2.2 \\
\hline Ruderal, segetal & 164 & 13.6 \\
\hline Species with a wide ecological amplitude & 23 & 1.9 \\
\hline Petrophytes, limestone, cretaceous, etc. & 22 & 1.8 \\
\hline Cultivated & 19 & 1.6 \\
\hline Total & 1210 & 100 \\
\hline
\end{tabular}


and meadow-steppe vegetation, e.g. Adonis vernalis L., Althaea officinalis L., Allium ursinum L., Anemone sylvestris L., Anemone ranunculoides L., Carex ericetorum Pollich, Carex leporine L., Carex praecox Schreb., Convallaria majalis L., Corydalis cava (L.) Schweigg. et Koerte, Lotus arvensis Pers.

About $13.6 \%$ of the investigated flora belongs to the ruderal and segetal group. Thus, Anagallis arvensis L., Cannabis ruderalis Janisch., Capsella bursa-pastoris (L.) Medik., Carduus acanthoides L., Cirsium setosum (Willd.) Besser, Consolida regalis S. F. Gray, Elytrigia repens (L.) Nevski, Galium aparine L., Senecio vernalis Waldst. \& Kit., Setaria glauca (L.) Beauv., Sinapis arvensis L., Sonchus arvensis L., Thlaspi arvense L., Veronica persica Poir., Viola arvensis Murray etc. have been found in all types of investigated anthropogenic landscapes.

The cultivated flora is represented by 19 species $(1.6 \%)$ in the agrolandscapes of Eastern Podilia. These are mainly crops grown in this area - Amorpha fruticosa L., Caragana arborescens Lam., Populus italica (Du Roi) Moench, Spiraeaalba Du Roi, etc. - types of cultivated trees and bushes that can be often seen in the gardens and parks of the region. In the investigated areas, they were found in anthropogenically-modified tracts.

Thus, ecological and cenotic analysis of flora sufficiently reflects the peculiarities of the vegetation of the investigated region. The predominance of the species of meadow-steppe, forest nemorose, meadow and meadow-bog ecological and cenotic groups proves the relative conservation of ecosystems. A significant number of the species of meadow, meadowbog, water, and coastal-water groups make up almost half of the total amount, which proves the hydrophylic nature of the flora in general. Therefore, the flora is typical for Holarctic areas with moderate climate regarding its ecological cenotic structure.

\section{CONCLUSIONS}

The general characteristic of the floristic diversity of Eastern Podilia is particularly important for its evaluation in areas with a high level of anthropogenic fragmentation of vegetation, as it represents the flora of the cenoses from different parts of the area. The peculiarities of floristic, biomorphological and ecologicalcenotic structures are used for floristic zoning of the area, distinguishing the main directions of anthropogenic transformation of phytobiota and the development of effective ways to preserve phytodiversity in the structure of the regional ecological network.

Received 1 July 2018 Accepted 14 December 2018

\section{References}

1. Andrienko TL, Blum OB, Vasser SP. The nature of Ukrainian SSR. The world of plants. Naukova Dumka, Kyiv. 1985. Russian.

2. Andrienko TL, Haluta PH, Kurkutsiev HN. Social and ecological significance of the nature-protected territories of Ukraine. Naukova Dumka, Kyiv. 1981. Russian.

3. Baranovski B, Khromykh N, Karmyzova L, Ivanko I, Lykholat Y. Analysis of the alien flora of Dnipropetrovsk Province. Biological Bulletin of Bogdan Chmelnitskiy Melitopol State Pedagogical University. 2016; 6(3): 419-29.

4. Bermudez RS, Cantos MCG. Development and validation of flora inventory management system. MSEUF Research Studies. 2012; 14(1): 4-13.

5. Bhojwani SS, Dantu PK. Conservation of phytodiversity. In: Plant Tissue Culture: An Introductory Text. India: Springer; 2013. p. 287-98.

6. Chandra A, Kewat AK. Phyto-diversity of selected stress sites of Garhwal Forest Division of Pauri Garhwal, Uttarakhand, India. Ann Pl Sci. 2017; 6(8): 1658-63.

7. Didukh YP. The Red book of Ukraine. The world of plants. Kyiv: Globalconsulting; 2009. Ukrainian.

8. Genung MA, Fox J, Williams NM, Kremen C, Ascher J, Gibbs J, Winfree R. The relative 
importance of pollinator abundance and species richness for the temporal variance of pollination services. Ecology. 2017; 98(7): 1807-16.

9. Gerstner K, Dormann CF, Stein A, Manceur AM, Seppelt R. Effects of land use on plant diversity - a global meta-analysis. J App Ecol. 2014; 51: 1690-700.

10. Honcharenko IA. Analysis of vegetation cover of the North-Eastern forest-steppe of Ukraine. Kyiv: Phitosotsiotsentr; 2003. Ukrainian.

11. Kadeba A, Nacoulma BMI, Ouedraogo A, Bachmann Y, Thiombiano A, Schmidt M, Boussim L. Land cover change and plants diversity in the Sahel: a case study from northern Burkina Faso. Ann for res. 2015; 58(1): 109-23.

12. Khan SW, Khatoon S, Abbas Q, Raza G, Hussain A. Inventory of the alpine flora of haramosh and bagrote valleys (karakoram range) district gilgit, gilgit-baltistan, Pakistan. Pak J Bot. 2016; 48(4): 1559-72.

13. Kumar R. Floristic richness in catchment areas of Papagini River - a tributary of River Pennar, Andhra Pradesh, India. Int J Environ. 2014; 3(1): 177-204.

14. Kuzemko AA, Steinbauer MJ, Becker T, Didukh YP, Dolnik C, Jeschke M, Naqinezhad A, Uğurlu E, Vassilev K, Dengler J. Patterns and drivers of phytodiversity in steppe grasslands of Central Podolia (Ukraine). Biodivers Conserv. 2016; 25(12): 2233.

15. Litvinskaia SA. Inventory and preservation of phytorrhage in the North-Western part of the Great Caucasus. Vesnyk of Melitopol State Pedagogical University. Biology. 2012; 3(6): 38-45. Russian.

16. Lykholat YV, Khromykh NA, Ivan'ko IA, Matyukha VL, Kravets SS, Didur OO, Alexeyeva AA, Shupranova LV. Assessment and prediction of the invasiveness of some alien plants under the climatic changes in the steppe Dnieper. Biosyst Divers. 2017; 25(1): 52-9.

17. Maltseva SY, Maltsev YI, Solonenko AM, Bren OG. Anthropogenic transformation of the flora of urbanoecosystems of the North- ern Pryazov territories. Biosyst Divers. 2017; 25(3): 222-7.

18. Malyshev LI. Floristic Spectra of the Soviet Union. History of flora and vegetation of Eurasia. 1972: 17-40. Ukrainian.

19. Mariničová P, Eliáš $\mathrm{P}$. The role of phytodiversity in riparian alder forests in supportingthe provision of ecosystem services. Acta Region Environ. 2016; 2: 47-51.

20. Mosyakin SL, Fedorchuk MM. Vascular Plants of Ukraine a nomenclatural checklist. Kyiv: M. G. Kholodny Botany Institute, 1999. Ukrainian.

21. Mudrak OV, Biliavskii HO, Mudrak HV. Scientific substantiation of expediency of creation of the regional landscape park "Dnister" (within Vinnitsa region). Human and the environment. Problems of neoecology. 2006; 8: 34-41. Ukrainian.

22. Mudrak OV. Environmental safety of Vinnytsia region. Vinnytsia: Miska drukarnia; 2008. Ukrainian.

23. Mudrak OV. Problems of preservation of biotic diversity of meadows as key areas of Podillia Ecological Network. The plants of of Eastern Europe: classification, ecology, protection. 2009: 150-5. Russian.

24. Mudrak OV, Mudrak HV. Features of biodiversity conservation in Podillia: theory and practice. Vinnytsia: LLC Nilan; 2013. Ukrainian.

25. Mudrak OV, Mudrak HV, Polishchuk VM, Kushnir SL, Elisavenko YA, Hanchuk MM, Bryndak TV. Standards of nature of Vinnytsya region. Vinnytsia: LLC Konsol; 2015. Ukrainian.

26. Mutke J, Jacobs R, Meyers K, Henning T, Weigend M. Diversity patterns of selected Andean plant groups correspond to topography and habitat dynamics, not orogeny. Fron Genet. 2014; 5: 351 .

27. Patyka VP, Solomakha VA, Burda RI, Boiko AL, Glazko VI, Glazko TT, Kalinchik MV, Petrovskii MO, Hubar SI, Skuriatin YM, Malienko AM, Polishchuk VP, Movchan YI, Solomakha TD, Vorobiov EO. 
Prospects for the use, conservation and reproduction of agrobiodiversity in Ukraine. Kyiv: Khimdzhest; 2003. Ukrainian.

28. Raunkiaer $\mathrm{K}$. The life forms of plants and statistical plant geography. London: Oxford University Press; 1934.

29. Ǩepka R, Šebesta J, Maděra P, Vahalík P. Comparison of the floodplain forest floristic composition of two riparian corridors: species richness, alien species and the effect of water regime changes. Biologia. 2015; 70(2): 208-17.

30. Salas-Morales SH, Meave JA, Trejo I. The relationship of meteorological patterns with changes in floristic richness along a large elevational gradient in a seasonally dry region of southern Mexico. Int J Biometeorol. 2015; 59: 1861-74.

31. Takhtadzhan AL. The system of magnoliophyte. Nauka, Lvov. 1987. Russian.

32. Tolmachev AI. Wealth of floras as an object of comparative study. Vestnik of Leningrad University. 1970; 9: 71-83. Ukrainian.

33. Volovik VM, Mudrak OV. Characteristics of floristic and faunistic diversity of a promising regional landscape park "Medium Pobuzhya". Visnyk of Vinnytsia State Agrarian University. 2007; 29: 19-30. Ukrainian.

34. Yavorska OG. Reserve objects of Vinnytsia. Vinnytsia: Veles; 2005. Ukrainian.

35. Zuo XA, Knops JMH, Zhao XY, Zhao HL, Zhang TH, Li YQ, Guo YR. Indirect drivers of plant diversity-productivity relationship in semiarid sandy grasslands. Biogeosciences. 2012; 9: 1277-89.

\section{Oleksandr Mudrak, Yuliia Ovchynnykova, Halyna Mudrak, Halyna Tarasenko}

\section{RYTU PODOLĖS (UKRAINA) TAKSONOMINĖ IR TIPOLOGINĖ FLOROS STRUKTŪRA}

\section{Santrauka}

Remiantis herbariumo duomenimis, literatūriniais ir kartografiniais šaltiniais, buvo atliktas Rytu Podolès nuosavo lauko floros tyrimas ir iqvertinta surinkta medžiaga. Florą sudare 1210 rūšių, priklausančių 526 gentims ir 123 šeimoms. Tiriamosios zonos floros struktūroje išskirtuose 5 skyriuose vyrauja magnolijūnai (Magnoliophyta) - 1183 rūšys (97,2 \%). Didesnę regiono fitogenetinių trąšų biomorfologinès struktūros dalị (88,6 \%) sudaro žoliniai augalai: polikarpiniai $(60,8 \%)$, monokarpiniai $(17,4 \%)$ ir jaunos rūšys $(10,4 \%)$. Vertinant fitobiotą pagal Raunkier ekobiomorfo rodyklès indeksą, nustatyta, kad tiriamojoje floroje vyravo hemikriptofitai $(47,9 \%)$ ir terofitai $(22,2 \%)$. Kriptofitai (dar skirstomi i geofitus, gelofitus ir hidrofitus) sudaré $17,6 \%$, fanerofitai ir chamefitai - $12,3 \%$. Tyrimo duomenimis, regiono floros ekologinëje ir keonotineje struktūroje vyrauja pievos ir stepių (191, arba $15,8 \%$ ), miško (185, arba 15,3 \%) ir ne miško (183, arba 15,1 \%) rūšių augmenija.

Raktažodžiai: rūšys, fitodiversiškumas, ekologinè ir keonotinè analizè, veiksniai 